\title{
Effect of palm kernel meal (Elaeis guineensis, Jacq, 1763) in the diet on digestive transit and some serum parameters in Nile tilapia (Oreochromis niloticus, Linnaeus, 1758)
}

\author{
Amakoé ADJANKE ${ }^{1,2^{*}}$, Kokou TONA ${ }^{1}$, Ibrahim Imorou TOKO $^{2}$ and \\ Messanvi GBEASSOR ${ }^{1}$ \\ ${ }^{1}$ Laboratory of Animal Physiology, Faculty of Science (FDS), University of Lome,01 P.O. Box 1515 Lome, \\ Togo. \\ ${ }^{2}$ Aquaculture and aquatic Ecotoxicology Research Unit, Faculty of Agronomy (FA), University of Parakou \\ (UP), 03 P.O. Box 61, Parakou, Benin. \\ *Corresponding author; E-mail: a_amakoe@hotmail.fr; Tel.: (+228) 90356531.
}

Received: 19-02-2021

Accepted: 29-09-2021

Published: 30-10-2021

\begin{abstract}
As part of the continuation of the thesis work on the valuation of palm kernel cake in the diet of Nile tilapia, a study was carried out from March $7^{\text {th }}$ to April $12^{\text {th }}, 2018$ at the Aquaculture Research and Development Unit of the University of Lome in Togo. It aims to evaluate the digestive use efficiency of palm kernel cake (PK) in Oreochromis niloticus. So, two lots of 180 male Oreochromis niloticus; juvenile of $57.14 \pm 4.43 \mathrm{~g}$ and adults of $144.04 \pm 7.65 \mathrm{~g}$ were each randomly distributed in 9 recirculate system concrete tanks of $600 \mathrm{~L}$, at 20 fish per tank, filled to 250 liters of water. They were fed two weeks with three isoprotein diets (32\% crude protein) in triplicate, distributed manually three times a day at $2 \%$ of the fish biomass; standard fish feed Raanan (RA) and two diets containing 30\% PK untreated (R3) or cooked in water for one hour (R3C). After a 2 days fasting, some fish were fed once again to satiety (8am). Then a sample of 6 fish per lot was euthanized in a clove solution. After blood sampling, the fish were dissected at $0 \mathrm{~h}, 1 \mathrm{~h}, 4 \mathrm{~h}, 8 \mathrm{~h}, 12 \mathrm{~h}$ and $24 \mathrm{~h}$ after feeding to measure blood and intestinal parameters. The results obtained show that raw PK is an unpalatable fibrous ingredient but well valued once cooked with a digestive improvement allowing good absorption of food micronutrients in both juveniles and adults. This absorption led to changing in the serum protein level for growth of fish and nitrogenous excretion in the form of urea. The cooking slowed the transit of the food into the digestive tract of tilapia, this can improve zootechnical performance of fish.
\end{abstract}

() 2021 International Formulae Group. All rights reserved.

Keywords: Digestive tract, blood total protein, blood urea, Tilapia, diets.

\section{INTRODUCTION}

Fish meal is the best source of protein for aquaculture feed because of its protein content (65 to $72 \%)$, the absence of antinutritional factors and its essential amino acid content for fish needs (Médale et Kaushik,
2009). It becomes necessary to find alternative protein sources to limit the dependence of aquaculture on fisheries products and to save marine resources (Richter et al., 2003). Several tests made with animal co-products (meat, blood, bone, feather meal) are now banned in 
Europe (Naylor et al., 2009). The most potential substitutes are vegetable protein sources. But the major challenge in fish nutrition is the weak use of available agroindustrial by-products, which pollute the environment (Ubani et al., 2013). In tilapia, raw materials were replaced with agroindustrial substitutes in feed to improve zootechnical performance similar to those based on conventional ingredients (Mouhamadou Amadou et Cheikh Tidiane, 2015). They are moringa leaf flour (Richter et al., 2003), cotton, peanut and copra cakes, tomato flour (Azaza et al., 2006) and palm kernel meal; often used in animal feed $(\mathrm{Ng}$, 2004). This ingredient, largely available, can be valued in fish farming because of its protein and energy composition (Adjanke et al., 2016; Imorou Toko, 2007). It contains about 20\% crude protein and $47 \%$ carbohydrates (Akinyeye et al., 2011). His cooking with water for one hour of this ingredient improves its nutritional quality (Adjanke et al., 2017). However, the digestive utilization and the assimilation of food macronutrients constitute a decisive step for its use by the metabolism (Ble et al., 2007). It is in this perspective this study was initiated to evaluate the digestive use efficiency of palm kernel cake in the Nile tilapia, Oreochromis niloticus.

\section{MATERIALS AND METHODS}

\section{Experimental procedure}

To evaluate the digestive transit of palm kernel cake in tilapia, two lots of 180 male tilapia Oreochromis niloticus; juvenile of $57.14 \pm 4.43 \mathrm{~g}$ and adults of $144.04 \pm 7.65 \mathrm{~g}$ were used. They were acclimatized to the new conditions for a week. Each lot was randomly distributed in 9 recirculate system concrete tanks of $600 \mathrm{~L}$ at 20 fish per tank, filled to 250 liters of water. The fish were fed for two weeks with three isoproteic diets (32\% crude protein) in triplicate, distributed manually three times a day at $2 \%$ of the fish biomass. The diets are standard fish feed Raanan (RA) and two diets containing 30\% PK untreated (R3) or cooked in water for one hour (R3C). The physicochemical parameters of the water (temperature, dissolved oxygen, $\mathrm{pH}$ ) were regularly monitored. At the end of this period, the fish were fasted for 2 days. On the 3rd day, some were refilled once again $(08 \mathrm{H})$ before depriving them of food again. A sample of 6 fish per lot was euthanized in a solution of clove (6 g / $10 \mathrm{~L}$ of water). After blood collection, the fish were dissected at $0 \mathrm{~h}, 1 \mathrm{~h}, 4$ $\mathrm{h}, 8 \mathrm{~h}, 12 \mathrm{~h}$ and $24 \mathrm{~h}$ after feeding to measure blood and intestinal parameters according to the method of Hocking et al. (2004), adapted to fish.

\section{Determination of the digestive transit}

After the dissection, the digestive tract was removed and measured. The digestive transit was evaluated from the contents weight of the different digestive tract compartments (stomach, proximal and distal guts). The weight of the digestive tract contents was obtained by the difference between the compartments of the fed fish and those of the unfed fish after the period of fasting.

\section{Determination of the biochemical composition of diets and blood}

Blood was collected from the fish at the end of the test of palm kernel cake in dry vacutainer tubes and 100 grams of experimental diets were finely ground using the hammer mill and wrapped in aluminum foil. The serum parameters analyzed included total protein and urea of blood. Samples were analyzed at the Food Technology Laboratory of the Togolese Institute for Agronomic Research (ITRA) at Lome.

\section{Determination of serum concentration of total protein and urea}

The collected blood is immediately centrifuged at $2500 \mathrm{rpm}$ for $15 \mathrm{~min}$ in a Shimadou brand centrifuge to collect the serum. The latter is used to determine the total protein and urea concentrations by the colorimetric method using a Thermo brand spectrometer.

Total fish blood proteins were determined using the Kjeldahl method (AOAC, 2000). The kit shown in Table 1 was used for 
serum urea analysis of fish according to the method presented in Table 2.

The following formula was used to calculate the concentration of urea:

$$
\begin{aligned}
& \text { Urea }\left(\frac{m g}{d L}\right) \\
& =\frac{\text { Abs Sample }- \text { Abs Witness }}{\text { Abs Standard }- \text { Abs Witness }} \times 50
\end{aligned}
$$

\section{Statistical analysis}

Data were analyzed by one-way analysis of variance (ANOVA I). The LSD Fischer test allowed homogeneous groups means discrimination. Differences were considered significant at 5\% level. Statistical analyses were performed using STATISTICA 5.1 program (Stat Soft, Inc.).

Table 1: Urea analysis kit component.

\begin{tabular}{lcc}
\hline Products & Elements & Composition \\
\hline Reagent 1 & Phosphate $\mathrm{pH} 6.7$ & $50 \mathrm{mmol} / \mathrm{l}$ \\
Tampon & EDTA & $2 \mathrm{mmol} / \mathrm{l}$ \\
& Salycilate sodium & $400 \mathrm{mmol} / \mathrm{l}$ \\
& Nitroprusiate sodium & $10 \mathrm{mmol} / \mathrm{l}$ \\
Reagent 2 & Hypochlorite sodium & $140 \mathrm{mmol} / \mathrm{l}$ \\
NClO & Hydroxyde sodium & $150 \mathrm{mmol} / \mathrm{l}$ \\
Reagent 3 & Urease & $30000 \mathrm{U} / \mathrm{l}$ \\
Enzymes & & $50 \mathrm{mg} / \mathrm{dl}$ \\
Standard & Aqueous urea & \\
& &
\end{tabular}

Table 2 : Urea analysis method.

\begin{tabular}{lccc}
\hline & Witness & Standard & Sample \\
\hline R1+R3 & $1.00 \mathrm{ml}$ & $1.00 \mathrm{ml}$ & $1.00 \mathrm{ml}$ \\
Standard & --- & $10 \mu \mathrm{L}$ & --- \\
Sample & --- & --- & $10 \mu \mathrm{L}$
\end{tabular}

Mix and incubate at $37^{\circ} \mathrm{C}$ for 5 minutes. Then add the reagent 2 .
Reagent 2
$1.00 \mathrm{ml}$
$1.00 \mathrm{ml}$
$1.00 \mathrm{ml}$

Mix and incubate 5 minutes à $37^{\circ} \mathrm{C}$. Measure the sample and standard absorbance (abs) compare to the witness. The reading is done at $580 \mathrm{~nm}$ wave length. 


\section{RESULTS}

\section{Survival rate}

Mean survival rates at the end of the experiment were $100 \%$ for juveniles in all lots; they were between $95 \%$ and $98.33 \%$ for adults. The statistical analysis showed no significant difference between the survival rates of the different lots $(\mathrm{P}>0.05)$.

\section{Effect of palm kernel cake in food on food transit}

Palm kernel cake has variously influenced the contents of different compartments of the digestive tract.

\section{Weight of stomach contents of fish fed after fasting}

The evolution of the average weight of stomach contents of fish fed after fasting is shown in Table 3. There was a progressive decrease in the average weight of stomach contents in all treatments in lot 1 . The decrease was more pronounced in fish fed $\mathrm{R} 3$ than those fed RA and R3C which were similar ( $p>0.05$ ).

The weight of stomach contents of fish in lot 2 increased slightly between the first and fourth hours after food ingestion (Table 3). This increase was similar for all treatments ( $p>$ 0.05 ). From the 4 th hour, the contents of the stomach gradually decreased in a similar manner in all treatments ( $\mathrm{p}>0.05)$.

\section{Weight of the proximal gut contents of fish fed after fasting}

During the first eight hours after food intake, the weight of the proximal gut contents gradually increased for all treatments in lot 1 (Table 4). It was high in fish fed RA and R3C and low in those fed R3 ( $p<0.05$ ). A decrease in the weight of the contents was observed beyond the eighth hour until the end. It was pronounced in fish of treatments RA and R3C compared to those of R3 ( $p<0.05$ ).

The proximal gut content in lot 2 increased similarly ( $p>0.05$ ) in RA and R3C fish during the first four hours after food intake. This increase in content continued until the eighth hour in R3 fish (Table 4). The rest of the time, there was a similar decrease in the contents of the proximal gut for all treatments $(\mathrm{p}>0.05)$.
Weight of distal gut contents of fed fish after fasting

The evolution of the average distal gut weight in fish fed only once after fasting is shown in Table 5. The weight of distal gut contents increased gradually and similarly until the 12th hour in all treatments in lot 1 ( $\mathrm{p}>$ 0.05 ). On the other hand, beyond the 12th hour, there was a similar decrease in the content of the distal gut ( $p>0.05)$.

In fish in Lot 2, the weight of distal gut contents increased for all treatments in the first eight hours (Table 5). This increase was pronounced but similar between the RA and R3C treatments ( $>>0.05)$ but low for the R3 treatment $(p<0.05)$. Beyond the eighth hour the content decreased for all treatments $(\mathrm{p}<0.05)$.

\section{Effect of palm kernel cake in food on blood parameters}

The serum parameters such as total proteins and blood urea were variously influenced in the different fish lots by the different treatments.

\section{Total protein concentration in the blood of fish fed after fasting}

The total protein concentration of the R3 treatment was significantly lower than RA and R3C treatments ( $\mathrm{p}<0.05)$ whose concentrations were comparable from the beginning to the 4th hour in all lots (Table 6). At the 4th hour, the total protein concentration of R3 peaked but was not significant at lot 1 . At the 8th hour (lot 1), the total serum protein concentration of R3 was lower than RA and R3C (p <0.05). Above 8 hours, this concentration is similar for all treatments but above $2.8 \mathrm{~g} / \mathrm{dL}$ in all lots ( $\mathrm{p}>0.05$ ).

\section{Urea concentration in the blood of fish fed after fasting}

The evolution of the concentration of urea in the blood of the different fish lots fed only once after fasting is shown in Table 7. It is noted that serum urea concentrations of $\mathrm{R} 3 \mathrm{C}$ treatment were generally lower than those of RA and R3 one hour after food intake until the end of the day ( $p<0.05)$. However, serum urea concentrations of R3 treatment were significantly higher than those of RA in lot 2 (p $<0.05)$. 
Table 3: Evolution of the average weight ( $\mathrm{g}$ ) of the stomach contents of fish lots fed after fasting.

\begin{tabular}{ccccccc}
\hline \multirow{2}{*}{ Hours } & \multicolumn{3}{c}{ Lot 1 } & \multicolumn{3}{c}{ Lot 2 } \\
\cline { 2 - 7 } & $\mathbf{R A}$ & $\mathbf{R 3}$ & $\mathbf{R 3 C}$ & $\mathbf{R A}$ & $\mathbf{R 3}$ & $\mathbf{R 3 C}$ \\
\hline 1 & $0.71 \pm 0.17^{\mathrm{a}}$ & $0.38 \pm 0.06^{\mathrm{c}}$ & $0.60 \pm 0.14^{\mathrm{b}}$ & $3.90 \pm 0.40^{\mathrm{a}}$ & $2.60 \pm 0.64^{\mathrm{b}}$ & $3.44 \pm 0.74^{\mathrm{a}}$ \\
4 & $0.43 \pm 0.05^{\mathrm{a}}$ & $0.21 \pm 0.04^{\mathrm{c}}$ & $0.32 \pm 0.11^{\mathrm{b}}$ & $4.25 \pm 0.94^{\mathrm{a}}$ & $3.31 \pm 0.04^{\mathrm{c}}$ & $3.94 \pm 0.38^{\mathrm{b}}$ \\
8 & $0.29 \pm 0.06^{\mathrm{a}}$ & $0.11 \pm 0.01^{\mathrm{b}}$ & $0.21 \pm 0.09^{\mathrm{a}}$ & $3.31 \pm 0.38^{\mathrm{a}}$ & $2.63 \pm 0.37^{\mathrm{b}}$ & $2.90 \pm 0.43^{\mathrm{b}}$ \\
12 & $0.02 \pm 0.01^{\mathrm{a}}$ & $0.02 \pm 0.01^{\mathrm{a}}$ & $0.06 \pm 0.03^{\mathrm{a}}$ & $1.55 \pm 0.17^{\mathrm{a}}$ & $0.39 \pm 0.11^{\mathrm{c}}$ & $1.06 \pm 0.21^{\mathrm{b}}$ \\
24 & $0.01 \pm 0.00^{\mathrm{a}}$ & $0.01 \pm 0.00^{\mathrm{a}}$ & $0.02 \pm 0.01^{\mathrm{a}}$ & $0.11 \pm 0.01^{\mathrm{b}}$ & $0.40 \pm 0.16^{\mathrm{a}}$ & $0.17 \pm 0.08^{\mathrm{b}}$ \\
\hline
\end{tabular}

RA: Standard food. R3: Food containing 30\% untreated palm kernel cake. R3C: Food containing 30\% palm kernel cake boiled in water for one hour. The different letters on the same line of the table indicate a significant difference between treatments (p $<0.05)$.

Table 4: Evolution of the average weight $(\mathrm{g})$ of the contents of the proximal gut of fish lots fed after fasting.

\begin{tabular}{ccccccc}
\hline \multirow{2}{*}{ Hours } & \multicolumn{3}{c}{ Lot 1 } & \multicolumn{3}{c}{ Lot 2 } \\
\cline { 2 - 7 } & $\mathbf{R A}$ & $\mathbf{R 3}$ & $\mathbf{R 3 C}$ & $\mathbf{R A}$ & $\mathbf{R 3}$ & $\mathbf{R 3 C}$ \\
\hline 1 & $0,08 \pm 0,04^{\mathrm{a}}$ & $0,04 \pm 0,01^{\mathrm{b}}$ & $0,09 \pm 0,03^{\mathrm{a}}$ & $0,93 \pm 0,06^{\mathrm{a}}$ & $0,32 \pm 0,00^{\mathrm{c}}$ & $0,43 \pm 0,11^{\mathrm{b}}$ \\
4 & $0,39 \pm 0,14^{\mathrm{a}}$ & $0,16 \pm 0,03^{\mathrm{b}}$ & $0,38 \pm 0,09^{\mathrm{a}}$ & $3,26 \pm 0,24^{\mathrm{a}}$ & $2,00 \pm 0,51^{\mathrm{c}}$ & $2,87 \pm 0,39^{\mathrm{b}}$ \\
8 & $0,58 \pm 0,14^{\mathrm{a}}$ & $0,25 \pm 0,05^{\mathrm{b}}$ & $0,51 \pm 0,13^{\mathrm{a}}$ & $2,93 \pm 0,90^{\mathrm{a}}$ & $2,39 \pm 0,58^{\mathrm{b}}$ & $2,86 \pm 0,88^{\mathrm{a}}$ \\
12 & $0,18 \pm 0,04^{\mathrm{a}}$ & $0,06 \pm 0,04^{\mathrm{b}}$ & $0,11 \pm 0,02^{\mathrm{ab}}$ & $1,26 \pm 0,47^{\mathrm{a}}$ & $0,51 \pm 0,14^{\mathrm{c}}$ & $0,82 \pm 0,13^{\mathrm{b}}$ \\
24 & $0,03 \pm 0,01^{\mathrm{a}}$ & $0,01 \pm 0,01^{\mathrm{a}}$ & $0,02 \pm 0,01^{\mathrm{a}}$ & $0,19 \pm 0,02^{\mathrm{a}}$ & $0,05 \pm 0,01^{\mathrm{c}}$ & $0,11 \pm 0,04^{\mathrm{b}}$ \\
\hline
\end{tabular}

RA: Standard food. R3: Food containing 30\% untreated palm kernel cake. R3C: Food containing 30\% palm kernel cake boiled in water for one hour. The different letters on the same line of the table indicate a significant difference between treatments (p $<0.05)$.

Table 5: Evolution of the average weight ( $\mathrm{g}$ ) of the distal gut contents of fish lots fed after fasting.

\begin{tabular}{ccccccc}
\hline \multirow{2}{*}{ Hours } & \multicolumn{3}{c}{ Lot 1 } & \multicolumn{3}{c}{ Lot 2 } \\
\cline { 2 - 7 } & $\mathbf{R A}$ & $\mathbf{R 3}$ & $\mathbf{R 3 C}$ & $\mathbf{R A}$ & $\mathbf{R 3}$ & $\mathbf{R 3 C}$ \\
\hline 1 & $0,03 \pm 0,01^{\mathrm{a}}$ & $0,02 \pm 0,01^{\mathrm{a}}$ & $0,02 \pm 0,01^{\mathrm{a}}$ & $0,11 \pm 0,00^{\mathrm{a}}$ & $0,06 \pm 0,00^{\mathrm{b}}$ & $0,13 \pm 0,01^{\mathrm{a}}$ \\
4 & $0,03 \pm 0,00^{\mathrm{a}}$ & $0,03 \pm 0,01^{\mathrm{a}}$ & $0,02 \pm 0,01^{\mathrm{a}}$ & $0,15 \pm 0,02^{\mathrm{a}}$ & $0,09 \pm 0,03^{\mathrm{b}}$ & $0,15 \pm 0,04^{\mathrm{a}}$ \\
8 & $0,15 \pm 0,03^{\mathrm{b}}$ & $0,13 \pm 0,04^{\mathrm{b}}$ & $0,24 \pm 0,03^{\mathrm{a}}$ & $1,50 \pm 0,46^{\mathrm{a}}$ & $1,19 \pm 0,29^{\mathrm{b}}$ & $1,61 \pm 0,43^{\mathrm{a}}$ \\
12 & $0,44 \pm 0,16^{\mathrm{a}}$ & $0,26 \pm 0,04^{\mathrm{b}}$ & $0,46 \pm 0,13^{\mathrm{a}}$ & $0,92 \pm 0,04^{\mathrm{a}}$ & $0,40 \pm 0,13^{\mathrm{b}}$ & $1,16 \pm 0,52^{\mathrm{a}}$ \\
24 & $0,01 \pm 0,01^{\mathrm{a}}$ & $0,01 \pm 0,01^{\mathrm{a}}$ & $0,01 \pm 0,01^{\mathrm{a}}$ & $0,17 \pm 0,05^{\mathrm{a}}$ & $0,09 \pm 0,01^{\mathrm{b}}$ & $0,12 \pm 0,03^{\mathrm{b}}$ \\
\hline
\end{tabular}

RA: Standard food. R3: Food containing 30\% untreated palm kernel cake. R3C: Food containing 30\% palm kernel cake boiled in water for one hour. The different letters on the same line of the table indicate a significant difference between treatments ( $p$ $<0.05)$. 
Table 6: Evolution of the total blood protein concentration $(\mathrm{g} / \mathrm{dL})$ of the different fish lots fed after fasting.

\begin{tabular}{|c|c|c|c|c|c|c|}
\hline \multirow{2}{*}{ Hours } & \multicolumn{3}{|c|}{ Lot 1} & \multicolumn{3}{|c|}{ Lot 2} \\
\hline & RA & R3 & R3C & RA & $\mathbf{R 3}$ & R3C \\
\hline 0 & $3,24 \pm 0,28^{a}$ & $2,96 \pm 0,15^{\mathrm{b}}$ & $3,59 \pm 0,15^{\mathrm{a}}$ & $3,52 \pm 0,24^{\mathrm{a}}$ & $3,40 \pm 0,24^{a}$ & $3,78 \pm 0,19^{a}$ \\
\hline 1 & $4,89 \pm 0,33^{\mathrm{a}}$ & $3,52 \pm 0,12^{\mathrm{b}}$ & $4,48 \pm 0,50^{\mathrm{a}}$ & $4,53 \pm 0,33^{\mathrm{a}}$ & $3,09 \pm 0,12^{b}$ & $4,39 \pm 0,30^{\mathrm{a}}$ \\
\hline 4 & $4,27 \pm 0,35^{\mathrm{a}}$ & $4,27 \pm 0,17^{\mathrm{a}}$ & $4,19 \pm 0,19^{a}$ & $4,34 \pm 0,26^{a}$ & $3,97 \pm 0,24^{b}$ & $4,11 \pm 0,15^{\mathrm{ab}}$ \\
\hline 8 & $3,81 \pm 0,04^{a}$ & $2,88 \pm 0,07^{\mathrm{b}}$ & $3,27 \pm 0,12^{\mathrm{a}}$ & $3,19 \pm 0,47^{\mathrm{a}}$ & $3,25 \pm 0,02^{\mathrm{a}}$ & $3,07 \pm 0,11^{b}$ \\
\hline 12 & $2,91 \pm 0,09^{\mathrm{a}}$ & $2,82 \pm 0,17^{\mathrm{a}}$ & $3,01 \pm 0,05^{\mathrm{a}}$ & $3,06 \pm 0,24^{b}$ & $3,38 \pm 0,01^{\mathrm{a}}$ & $3,53 \pm 0,15^{\mathrm{a}}$ \\
\hline 24 & $3,10 \pm 0,19^{a}$ & $2,92 \pm 0,36^{a}$ & $3,16 \pm 0,30^{\mathrm{a}}$ & $3,37 \pm 0,02^{\mathrm{a}}$ & $3,32 \pm 0,06^{\mathrm{a}}$ & $3,56 \pm 0,07^{\mathrm{a}}$ \\
\hline
\end{tabular}

RA: Standard food. R3: Food containing 30\% untreated palm kernel cake. R3C: Food containing 30\% palm kernel cake boiled in water for one hour. The different letters on the same line of the table indicate a significant difference between treatments $(p$ $<0.05)$.

Table 7: Evolution of serum urea concentration $(\mathrm{mg} / \mathrm{dL})$ of different fish lots fed after fasting.

\begin{tabular}{|c|c|c|c|c|c|c|}
\hline \multirow{2}{*}{ Hours } & \multicolumn{3}{|c|}{ Lot 1} & \multicolumn{3}{|c|}{ Lot 2} \\
\hline & $\mathbf{R A}$ & $\mathbf{R 3}$ & R3C & $\mathbf{R A}$ & $\mathbf{R 3}$ & R3C \\
\hline 0 & $8,18 \pm 0,46^{\mathrm{b}}$ & $5,70 \pm 0,37^{\mathrm{c}}$ & $10,73 \pm 0,50^{\mathrm{a}}$ & $7,14 \pm 1,93^{\mathrm{a}}$ & $4,27 \pm 0,73^{\mathrm{c}}$ & $6,06 \pm 1,09^{\mathrm{b}}$ \\
\hline 1 & $14,82 \pm 0,99^{\mathrm{a}}$ & $8,71 \pm 1,91^{\mathrm{c}}$ & $10,56 \pm 0,02^{\mathrm{b}}$ & $9,10 \pm 1,33^{\mathrm{a}}$ & $5,10 \pm 1,45^{\mathrm{b}}$ & $5,97 \pm 0,48^{\mathrm{b}}$ \\
\hline 4 & $11,93 \pm 0,70^{\mathrm{b}}$ & $13,64 \pm 0,93^{a}$ & $9,97 \pm 0,14^{\mathrm{c}}$ & $7,31 \pm 1,69^{b}$ & $9,29 \pm 0,85^{\mathrm{a}}$ & $5,13 \pm 0,48^{c}$ \\
\hline 8 & $10,89 \pm 1,47^{\mathrm{a}}$ & $9,53 \pm 0,50^{\mathrm{ab}}$ & $8,18 \pm 0,22^{\mathrm{b}}$ & $6,39 \pm 0,60^{b}$ & $8,20 \pm 2,42^{\mathrm{a}}$ & $4,52 \pm 0,12^{c}$ \\
\hline 12 & $8,52 \pm 0,50^{\mathrm{a}}$ & $7,76 \pm 0,59^{\mathrm{ab}}$ & $6,80 \pm 1,46^{\mathrm{b}}$ & $6,58 \pm 0,60^{\mathrm{b}}$ & $10,15 \pm 1,33^{\mathrm{a}}$ & $4,25 \pm 1,21^{\mathrm{c}}$ \\
\hline 24 & $8,44 \pm 0,58^{a}$ & $8,88 \pm 2,39^{a}$ & $6,65 \pm 0,95^{\mathrm{b}}$ & $12,31 \pm 1,21^{\mathrm{a}}$ & $12,77 \pm 0,97^{\mathrm{a}}$ & $8,89 \pm 2,42^{b}$ \\
\hline
\end{tabular}

RA: Standard food. R3: Food containing 30\% untreated palm kernel cake. R3C: Food containing 30\% palm kernel cake boiled in water for one hour. The different letters on the same line of the table indicate a significant difference between treatments $(\mathrm{p}$ $<0.05$ ). 


\section{DISCUSSION}

Physico-chemical parameter values were within the optimal range for the normal physiological functioning of tilapia (Akinwole et al., 2014). These parameters did not influence the results as the experimental culture system allowed the fish to grow and survive by providing adequate water quality throughout the trial (Amoussou et al., 2016). During the experiments, whatever the diet and the age, the fish adapted themselves and presented an interesting survival rate which varied between 95 and $100 \%$. Similar results were obtained by Abdel-Tawwab et al. (2010). The mortalities recorded in the fish of lot 2 could be attributed to the sensitivity of these fish to manipulations (El-Sayed, 2006).

Food intake in fish most often depends on experimental conditions (Moreau, 1996). Appetite reductions are observed in fish after fasting. In this study, variability in dietary intake was observed in treatments of different batches. That would be due according to Azaza et al. (2006) to a difference in chemical composition of the food and its palatability. The R3 diet would be less palatable and richer in fiber than R3C and RA. In addition, feed transit was slower in all intestinal compartments of fish that ate RA and R3C compared to fish that consumed R3. This process would be related to the nature of the untreated local food (R3) which would probably be more fibrous than the others (RA and R3C). These results are consistent with the analyzes made by Médale et Burel (2014). According to them, the insoluble fibers (cellulose, hemicellulose, lignin, etc.) increase the speed of the intestinal transit (peristalsis stimulation), thus reducing the contact time of the food components with the digestive enzymes and the cells of the intestinal mucosa, but also trap the lipids and proteins of the food in a network that prevents access of digestive enzymes to their substrate. Palm kernel cake is an ingredient or raw material with a low protein content and a high proportion of fiber. Fiberrich compounds can act by altering the activity of digestive enzymes by absorption and immobilization (Richter et al., 2003; Konan et al., 2017). In addition, plant-based ingredients contain anti-nutritional factors (ANFs) that inhibit the activity of digestive enzymes and the speed of intestinal transit (Médale et Burel, 2014). Reasonable fiber in the feed $(<8 \% \mathrm{DM})$ can, however, improve fish growth because it is a ballast in the bolus that regulates the rate of intestinal transit (NRC, 2011). In addition, there is a longer duration of evacuation of the food in the digestive tract of the fish. This would be due to the adaptation of the fish on the one hand to the return of a fast and on the other hand to the method of study of the transit (Amoussou et al., 2016; Riche et al., 2004). Indeed, the digestive transit in fish is studied from markers whose presence in faeces marks the time of transit (Ly et $\mathrm{Ba}, 2015$ ). Serum proteins tend to increase soon after food intake. Similar results were observed in the same species by Abdel-Tawwab et al. (2010). In this study, the increase in serum proteins in RA and R3C lots may be due to the improvement in protein quality of the food (Lundstedt et al., 2002). The protein synthesis capacity differs depending on the tissue involved. The liver is the major organ for protein synthesis. The synthesized proteins are then retained in the white muscle of the fish (50 to 70\%). During a fast, the protein synthesis does not change but the degradation of amino acids for the production of glucose increases. When fish are fed, protein synthesis increases depending on the availability of substrates. Increased hepatic activity of protein metabolizing enzymes when fish were fed RA and R3C may indicate the use of excess dietary amino acids for growth (Abdel-Tawwab, 2012). The majority (80\%) of nitrogen from nitrogen catabolism is excreted in ammonia form (Audic, 2006). Ammonia (NH3) is extremely toxic but, at physiological $\mathrm{pH}$, this compound is in ionized form ( $\mathrm{NH} 4+$ ). This form is less toxic and is eliminated by gills or urine. A small fraction of nitrogen from nitrogen catabolism is excreted as urea, however with variability by age and rearing conditions.

\section{Conclusion}

This study revealed that cooking slowed the transit of this food into the digestive tract of tilapia, which allowed this food micronutrients 
to be longer in contact with the cells of the intestinal epithelium and thus favored their absorption in both juveniles and adults. Moreover, this absorption is characterized by a variation of the serum protein level for the growth of the fish and the nitrogen excretion in the form of urea. This could improve zootechnical performance with this diet in order to reduce significantly the cost of feeding fish.

\section{COMPETING INTERESTS}

The authors declare that there is no competing interests in relation to this article.

\section{AUTHORS' CONTRIBUTIONS}

AA is the principal investigator and was involved in all phases of the work of this study, the design of themes, the conduct of the experiment, the analysis and the interpretation of data and writing of the article. KT, IIT and MG contributed to the correction of the article.

\section{ACKNOWLEDGMENTS}

The authors express their gratitude to the PARRAF (Programme d'Appui à la Recherche en Réseau en Afrique) and PPAAOTogo (Programme de Productivité Agricole en Afrique de l'Ouest-Togo) programs for their financial support of this study.

\section{REFERENCES}

Abdel-Tawwab M, Ahmad MH, Khattab YAE, Shalaby AME. 2010. Effect of dietary protein level, initial body weight, and their interaction on the growth, feed utilization, and physiological alterations of Nile tilapia, Oreochromis niloticus (L.). Aquaculture, 298: 267-274.

Abdel-Tawwab M. 2012. Effects of dietary protein levels and rearing density on growth performance and stress response of Nile tilapia, Oreochromis niloticus (L.). International Aquatic Research, 4: 3. DOI: https://doi.org/10.1186/20086970-4-3

Adjanke A, Tona K, Agbohessi PT, Imorou Toko I, Gbeassor M. 2016. Current situation of fish farming in Togo. Int. J.
Biol. Chem. Sci., 10(5): 2015-2024. DOI: http://dx.doi.org/10.4314/ijbcs.v10i5.6

Adjanke A, Tona K, Imorou Toko I, Gbeassor M. 2017. Effects of technological treatments of dietary palm kernel meal on feed intake, growth and body composition of Oreochromis niloticus reared in concrete tanks. The International Journal of Biotechnology, 6(1): 11-18. DOI: 10.18488/journal.57.2017.61.11.18

Akinwole AO, Dauda AB, Oredein TA. 2014. Effect of aeration on selected water quality parameters in freshwater fish culture. Int. J. Biol. Chem. Sci., 8(6): 2858-2865.

DOI: http://dx.doi.org/10.4314/ijbcs.v8i6.42

Akinyeye RO, Adeyeye EI, Fasakin O, Agboola A. 2011. Physico-chemical properties and anti-nutritional factors of palm fruit products (Elaeis Guineensis Jacq.) from Ekiti State Nigeria. Electronic Journal of Environmental, Agricultural and Food Chemistry, 10(5): 2190-2198.

Amoussou TO, Toguyeni A, Imorou Toko I, Chikou A, Youssao Abdou Karim I. 2016. Caractéristiques biologiques et zootechniques des tilapias africains Oreochromis niloticus (Linnaeus, 1758) et Sarotherodon melanotheron Rüppell, 1852 : une revue. Int. J. Biol. Chem. Sci., 10(4): $\quad 1869-1887 . \quad$ DOI: http://dx.doi.org/10.4314/ijbcs.v10i4.35

AOAC-Association of Official Analytical Chemists. 2000. Official methods of analysis. Washington, D.C. USA.

Audic M. 2006. Etude de la nutrition des saumons et contribution à la création d'une filière de production de saumons label rouge. Ecole Nationale Vétérinaire de Toulouse. Thèse pour l'obtention du grade de Docteur Vétérinaire. p 40.

Azaza MS, Mensi F, Imorou Toko I, Dhraief M, Abdelmouleh BB, Kraïem MM. 2006. Effets de l'incorporation de la farine de tomate dans l'alimentation du tilapia du Nil (Oreochromis niloticus, L., 1758) en élevage dans les eaux géothermales du sud tunisien. Bull. Inst. Natn. Scien. Tech. Mer de Salammbô, 33: 47-58. http://hdl.handle.net/1834/4238 
Ble MC, Arfi R, Yeboua AF, Diopoh KJ. 2007. Qualité nutritive de l'alimentation naturelle du tilapia Oreochromis niloticus en élevage extensif dans des étangs de barrage (côte d'ivoire). BFPP/Bull. Fr. Pêche Piscic., 385 : 01-16. DOI : http://dx.doi.org/10.1051/kmae:2007001

El-Sayed AFM. 2006. Tilapia Culture. CABI Publishing: Oxfordshire.

Hocking PM, Zaczek V, Jones EK, Macleod MG. 2004. Different concentrations and sources of dietary fibre may improve the welfare of female broiler breeders. Bri. Poult. Sci., 45: 9-19.

Imorou Toko I. 2007. Amélioration de la production halieutique des trous traditionnels à poisson (whedo) du delta de l'Ouémé (sud du Benin) par la promotion de l'élevage du poisson chat, Clarias gariepinus et Heterobranchus longifilis. Thèse de Doctorat en science biologique, Université notre Dame de la paix, Belgique, p 186.

Konan KJ, Atse BC, Kouassi NJ. 2017. Régime et rythme d'activité alimentaires de Tylochromis jentinki (Steindachner, 1895) dans la lagune Ebrié (Côte d'Ivoire). Int. J. Biol. Chem. Sci., 11(4): 1601-1610. - DOI: http://dx.doi.org/10.4314/ijbcs.v11i4.16

Lundstedt LM, Melo JFB, Santos-Neto C, Moraes G. 2002. Diet influences proteolytic enzyme profile of the South American catfish Rhamdia quelen. In Proceedings of the International Congress on the Biology of Fish biochemistry and physiology advances in finfish aquaculture, Vancouver; 2002:22-25.

Ly MA, BA CT. 2015. Effets d'une partielle substitution de la farine de poisson par la farine de soja sur la croissance des juvéniles de la perche du Nil (Lates niloticus, Linnaeus 1758). Int. J. Biol. Chem. Sci., 9(3): 1477-1484. DOI: http://dx.doi.org/10.4314/ijbcs.v9i3.30

Médale F, Kaushik S. 2009. Les sources protéiques dans les aliments pour les poissons d'élevage. Cah Agric, 18 : 103111. DOI: 10.1684/agr.2009.0279.
Médale F, Burel C. 2014. Les sources de protéines dans l'alimentation du bétail ; Quid de l'utilisation des protéines d'origine végétale en aquaculture. (Nutrition, Métabolisme, Aquaculture), Aquapôle INRA. OCL, 21(4) D406 p 115.

Mouhamadou Amadou LY, Cheikh Tidiane BA. 2015. Effets d'une partielle substitution de la farine de poisson par la farine de soja sur la croissance des juvéniles de la perche du Nil (Lates niloticus, Linnaeus 1758). Int. J. Biol. Chem. Sci., 9(3): 1477-1484. DOI: http://dx.doi.org/10.4314/ijbcs.v9i3.30

Naylor RL, Hardy RW, Bureau DP, Chiu A, Elliott M, Farrell AP, Forster I, Gatlin DM, Goldburg RJ, Hua K, Nichols PD. 2009. Feeding aquaculture in an era of finite resources. P. Natl. Acad. Sci. USA, 106: 15103- 15110.

$\mathrm{Ng}$ W-K. 2004. The potential use of palm kernel meal in aquaculture feeds. Fish Nutrition Laboratory, School of Biological Sciences, University Sains Malaysia. Penang 11800, Malaysia, 8(1): 38-39.

NRC (National Research Council). 2011. Nutrition Requirements of Fish. National Academy Press: Washington D.C. (USA).

Riche MD, Haley I, Oetker M, Garbrecht S, Garling DL. 2004. Effect of feeding frequency on gastric evacuation and the return of appetite in tilapia (Oreochromis niloticus) (L.). Aquaculture, 234 (1-4): $657-673$.

Richter N, Siddhuraju P, Becker K. 2003. Evaluation of nutritional quality of moringa (Moringa oleifera Lam.) leaves as an alternative protein source for Nile tilapia (Oreochromis niloticus L.). Aquaculture, 217: 599-611.

Ubani O, Atagana HI, Thantsha MS. 2013. Biological degradation of oil sludge: A review of the current state of development. Afr. J. Biotechnol., 12(47): 6544-6567. DOI: 10.5897/AJB11.1139 